DOI: $10.31393 /$ reports-vnmedical-2019-23(1)-07

удк: 616.36-003.826-036.1-003.9-091.8

\title{
ХРОНІЧНІ СТЕАТОГЕПАТИТИ В ТРЕПАНОБІОПТАТАХ ПЕЧІНКИ: ПАТОМОРФОЛОГІЯ АКТИВНОСТІ ТА РЕПАРАТИВНИХ ПРОЦЕСІВ
}

\author{
Туманський В.О., Фень С. В., Туманська Л.М.
}

Запорізький державний медичний університет (пр. Маяковського, 26, м. Запоріжжя, Україна, 69035)

Статтю отримано 9 листопада 2018 р.; прийнято до друку 19 грудня 2018 p.

Відповідальний за листування: e-mail: v.tumanskiy@gmail.com

\begin{abstract}
Анотація. Мета роботи - охарактеризувати можливості патоморфологічного визначення в трепанобіоптатах печінки активності хронічного стеатогепатиту різного генезу і спрямованості репаративних процесів. Гістологічними, гістохімічними й імуногістохімічними методами досліджена печінка 160 хворих на алкогольний стеатогепатит (ACГ), 123 хворих на неалкогольний стеатогепатит (НАСГ), 30 хворих на хронічний вірусний гепатит С, а також 30 гепатобіоптатів пацієнтів, які не хворіли на стеатогепатит. Визначено, що патоморфологічними параметрами активності АСГ і НАCГ $\epsilon$ зростання тяжкості та поширення стеатозу гепатоцитів печінки; збільшення числа гепатоцитів з тільцями МалоріДенка і балонних гепатоцитів; інтенсифрікація стеатонекрозу, балонного лізису, апоптозу і фрероптозу гепатоцитів; зростання кількості та розширення вогнищ стеатонекрозу в печіниі; поширення вогнищевої та дифузної лейкоцитарно-лімфоцитарної інфрільтрації часточок печінки. Генез стеатогепатиту (алкогольний, неалкогольний, вірусний) уточнюється тільки з урахуванням відповідних клініко-лабораторних даних пацієнта. Особливостями репаративних процесів у печінціє: дифреренціювання прогеніторних клітин печінки через проміжні гепатобіліарні і гепатоцитоподібні клітини в гепатоцити за наявності ламініну в печінкових часточках; ранній розвиток перицелюлярного фріброзу та відстрочена активація дуктулярної реакції з підсиленням портального і мостоподібного портально-портального фріброзу; фріналом фріброзу є мікронодулярний цироз печінки перисинусоїдально-перицелюлярного або портально-Z1-Зперисинусоидального типу. Отже, в адекватному трепанобіоптаті печінки є можливість встановити активність НАСГ і АСГ (або ї̈ відсутність), тип і ступінь тяжкості фіброзу печінки, а також ступінь виразності і спрямованість репаративних процесів у печінці.

Ключові слова: стеатогепатит, патоморфологія, репаративні процеси, біопсія печінки.
\end{abstract}

\section{Вступ}

Неалкогольна жирова хвороба печінки (НАЖХП), що включає неалкогольний жировий гепатоз і неалкогольний стеатогепатит (НАСГ), охоплює від 17 до 46\% дорослого населення світу [22]. НАСГ ускладнюється фріброзом, цирозом печінки і гепатоцелюлярною карциномою (ГЦК), а цироз печінки на тлі НАСГ входить в число перших трьох показань до трансплантації печінки [12]. За даними ВООЗ зловживання алкоголем щорічно призводить до смерті близько 3,3 мільйона осіб, від алкогольного стеатогепатиту (АСГ) і цирозу вмирає $5,9 \%$ населення земної кулі [24].

Відповідно до керівництв Американських та Європейських асоціацій останніх років важливе значення в діагностиці НАЖХП, НАСГ і АСГ мають як неінвазивні методи (ультразвукова діагностика, комп'ютерна томографрія, магнітно-резонансна томографія, еластографрія печінки, рівні маркерів фіброзу [NFS, FIB-4, ELF, FibroTest], гама-глутамілтранспептидази, алані нової і аспарагінової трансаміназ), так і біопсія печінки, яка визначає патоморфологічні (ПМ) ознаки активності стеатогепатиту, стадію фіброзу печінки і рано виявляє ГЦК $[8,11,12]$. Біопсія печінки незамінна для диференційної діагностики НАЖХП, НАСГ і аутоімунного гепатиту [10], а також для оцінки терапевтичного ефекту лікування стеатогепатиту [8].

До теперішнього часу триває пошук об'єктивних ПМ ознак активності цих захворювань, прийнятних для діагностики в трепанобіоптаті печінки $[5,19]$. В останні роки також досліджуються репаративні процеси в печінці при НАСГ та АСГ $[13,26]$, серед яких найменш вивчені особливості регенерації гепатоцитів.

Meта дослідження - охарактеризувати можливості патоморфологічного визначення активності хронічного стеатогепатиту різного ґенезу і спрямованості репаративних процесів у трепанобіоптатах печінки.

\section{Матеріали та методи}

Патоморфологічними методами досліджена печінка 315 пацієнтів: 160 хворих на АСГ 25-63 років (45 трепанобіоптатів печінки і печінка 87 померлих хворих), 123 трепанобіоптати печінки хворих на НАСГ 25-74 років, 30 трепанобіоптатів печінки пацієнтів 23-55 років, хворих на хронічний вірусний гепатит С (ХВГ С), асоційований зі стеатозом печінки, а також 30 гепатобіоптатів пацієнтів 25-65 років, які не хворіли на стеатогепатит.

Для патоморфологічних (ПМ) досліджень матеріал печінки фріксували в 10\% забуференому формаліні і заливали в парафін. Для мікроскопічної діагностики серійні парафінові зрізи забарвлювали гематоксиліном і еозином, методом Ван-Гізон і Масон-триколор. Тривалентне залізо $\mathrm{Fe}^{3+}$ виявляли в парафрінових зрізах методом Перлса, двовалентне залізо $\mathrm{Fe}^{2+}$ - методами Тірмана-Шмельцера і Хьюкіла-Пута. У парафінових зрізах виконували імуногістохімічні (IГX) дослідження із застосуванням системи детекції UltraVision Quanto HRP + DAB System ("Thermo Scientific", США) і вибіркових панелей 
антитіл: для ідентифікації прогеніторних клітин печінки - Polyclonal Ra a-Hu CD 117, c-kit ("DAKO", Данія), Мо aHu CD34, Clone QBEnd/10 ("Thermo Scientific", CШA), Mo a-Hu CD44 Std./HCAM Ab-4, Clone 156-3C11 ("Thermo Scientific", США), Mo a-Hu CD56, Clone T199 ("NeoMarkers" США); для визначення гепатоцитів HepPar-1 Mo a-Hu Hepatocyte, Clone QBEnd/10 ("Thermo Scientific", CШA), Rb a-Hu Alpha-1-Fetoprotein ("Thermo Scientific", США); для виявлення біліарних клітин - Мо аHu Keratin 7, Clone OV-TL 12/30 ("Thermo Scientific", CША), Mo a-Hu Cytokeratine 19, Clone RCK 108 ("DAKO", CША); для визначення клітин Купфера і макрофрагів - Мо а-Hu CD68, Clone PG-M1 ("DAKO", Данія); для ідентифікації фіброгенних клітин печінки - Mo a-Hu Alpha Smooth Muscle Actin (a-SMA), Clone 1A4 ("DAKO", Данія); для визначення складу позаклітинного матриксу (ПКМ) - Rb Laminin Ab-1 ("Thermo Scientific", СШA), Rb a-Hu Collagen type I, clone RAH C11-0,1 ("Имтек", Росія), Rb a-Hu Collagen type III, clone RAH C33 ("Имтек", Росія), Мо aHu Collagen type IV Ab-3, clone CIV 22 + PHM 12 ("Thermo Seientific", США); для ідентифрікації імуноцитів - Mo a-Hu CD4, Clone MT310 ("DAKO", Данія), Mo a-Hu CD8, T-cell Clone C8 / 144B ("DAKO", Данія), Mo a-Hu Plasma Cell Ab-1, Clone LIV3G11 ("NeoMarkers", CШA), Mo a-Hu CD5, Clone 5/54/F6 ("DAKO", Данія); Mo a-Hu CD45R0, T-Cell, Clone UCHL1 ("DAKO", Данія); для виявлення проліферації клітин - Mo a-Hu Ki-67 Antigen, Clone SP6 ("NeoMarkers", США).

У препаратах, забарвлених гематоксиліном і еозином, у стандартизованій площі гістологічного зрізу печінки (СПГЗП) у фотокамері Camedia C5060WZ "Olympus 3040" (Японія) в мікроскопі Axioplan 2 "Carl Zeiss" (Німеччина) при збільшенні x400 за D.E. Kleiner et al. [15] градуювали ступінь стеатозу печінки: слабкий S1 стеатоз (стеатоз 5-33\% гепатоцитів); помірний S2 стеатоз (стеатоз 34-66\% гепатоцитів) і тяжкий S3 стеатоз (стеатоз $>66 \%$ гепатоцитів). Ступінь накопичення заліза в печінці оцінювали за відсотком залізовмісних клітин (ЗВК) в СПГЗП за G.D. LeSage в модифікації M. Torbenson [21]: виділяли мінімальний G1 ступінь (<5\% 3ВК), легкий G2 ступінь (5-30\% ЗВКК), помірний G3 ступінь (31-60\% ЗВК) і тяжкий G4 ступінь (>60\% ЗВК). У парафрінових зрізах, забарвлених за Ван-Гізон і Масон-триколор, згідно модифікованої градації Е. M. Brunt et al. [6] визначали перисинусоїдально-перицелюлярний або портально- $Z_{1}$ Зперисинусоїдальний тип фіброзу печінки, а також ступінь його тяжкості: легкий - $\mathrm{F}_{1}$, помірний - $\mathrm{F}_{2}$, тяжкий $\mathrm{F}_{3}$ фіброз і $\mathrm{F}_{4}$ цироз печінки. В СПГЗП при збільшенні x200 у відповідно забарвлених препаратах печінки фотоцифровою морфометрією (ФЦММ) в програмі Image J [17] вимірювали площі депонування Масон-триколорпозитивного ПКМ, a-SMA + клітин та колагену I, III і IV типу.

Статистичну обробку отриманих результатів проводили в програмі "STATISTICA® for Windows 6.0" (StatSoft Inc., США, ліцензія № AXXR712D833214FAN5). Гіпотезу про нормальність розподілу досліджуваних показників перевіряли за критерієм Шапіро-Уілка. Для даних, розподілених за нормальним законом, обчислювали середнє значення (М), середнє квадратичне відхилення (б), стандартну помилку репрезентативності середнього значення (m), розраховували 95\% довірчий інтервал. Достовірність відмінностей визначали за допомогою tкритерію Стьюдента. Дані, розподіл яких відрізнявся від нормального, представляли за допомогою медіани і міжквартильного розмаху Ме (Q1; Q3); порівняння даних, отриманих у 3 групах проводили за Н критерієм Краскела-Уоліса. Для всіх видів аналізу відмінності вважали достовірними при $р<0,05$.

\section{Результати. Обговорення}

3 клініко-прогностичних позицій при хронічному стеатогепатиті в трепанобіоптаті печінки патоморфологу необхідно визначити активність стеатогепатиту (або ії відсутність), наявність і ступінь виразності репаративних процесів, тип і ступінь тяжкості фіброзу печінки або наявність цирозу печінки. Встановлення таких непростих патоморфологічних параметрів хронічного стеатогепатиту можливо тільки в адекватному за способом фріксації тканини, довжині і числу стовпчиків трепанобіоптаті печінки. Виконання більшості гістохімічних і ІГX діагностичних методик забезпечує фіксація стовпчиків тканини печінки в забуференому $10 \%$ розчині нейтрального формаліну на фоссратному буфері з рН 6,8-7,4. Для запобігання помилки вибірки при біопсії рекомендується застосування товстої черезшкірної голки з внутрішнім діаметром не менше 1,6 мм і відбір 2-5 стовпчиків тканини печінки довжиною 15-18 мм [23]. За таких умов в 1 лінійному см стовпчика тканини біоптату печінки можна отримати 6 повних портальних триад, а в 2-5 стовпчиках трепанобіоптату печінки - від 16 до 40 повних портальних триад і від 20 до 50 профілів дольок печінки, що особливо важливо для оцінки типу і тяжкості фріброзу печінки.

Проведені дослідження визначили найбільш значущі ПМ ознаки НАСГ і АСГ: наявність стеатозу гепатоцитів певних зон печінкових часточок, балонних гепатоцитів $\mathrm{i}$ гепатоцитів з тільцями Малорі-Денка, апоптозу і стеатонекрозу гепатоцитів, дрібних вогнищ синусоїдального ліпопеліозу, дрібновогнищевих інфільтратів з нейтрофрілів, еозинофілів, лімфоцитів і макрофагів. У хворих на АСГ і АСГ в біоптатах печінки також виявляються дрібні вогнища некрозу певних ділянок печінкових часточок, оточені перифокальною запально-клітинною інфільтрацією. Для НАСГ и АСГ характерним є розвиток перисинусоїдально-перицелюлярного і портально-Z1Зперисинусоїдального фіброзу печінки різного ступеню тяжкості. Серед патологів, що спеціалізуються в гепатології, єдиної думки про диференційні ПМ ознаки НАСГ і АСГ поки не склалося. На думку FLIP Pathology Consortium [5] для встановлення діагнозу НАСГ в біоптаті печінки необхідна наявність стеатозу, балонних гепатоцитів і лобулярного запалення одночасно. Основ- 
ними ПМ ознаками АСГ є стеатоз, гепатоцелюлярне балонування, некроз і лобулярне запалення, часто з переважанням нейтрофільних лейкоцитів [11]. Відповідно до Z.M. Younossi et al. [25], НАСГ діагностується при будь-якому ступеню стеатозу печінки при наявності центролобулярного балонування і / або тілець Малорі-Денка, а також при будь-якому ступеню стеатозу печінки разом з центролобулярним перицелюлярним/перисинусоїдальним і мостоподібним фріброзом печінки.

На нашу думку, ПМ зміни, що спостерігаються в трепанобіоптаті печінки з обмеженим обсягом тканини, є недостатніми для диференційної діагностики АСГ НАСГ. До аналогічного висновку прийшли також і інші фахівці з патоморфології печінки [19]. Ґенез стеатогепатиту (алкогольний, неалкогольний, токсичний, медикаментозний) в трепанобіоптаті печінки уточнюється тільки з урахуванням відповідних клініко-лабораторних даних пацієнта. Що рекомендують враховувати для диференційної діагностики? Діагноз АСГ підозрюють при фріксованому в медичній документації регулярному вживанні алкоголю >20 г/добу у жінок і >30 г/добу у чоловіків, разом з наявністю клінічних і / або лабораторних відхилень, які свідчать про дисфункцію печінки [4]. Оскільки високий відсоток пацієнтів з гістологічно встановленим АСГ приховують зловживання алкоголем, всім безсимптомним пацієнтам, які споживають критичну кількість алкоголю, після біопсії рекомендується пройти відповідні скринінгові дослідження печінки [4]. Згідно останніх рекомендацій Американської асоціації з вивчення захворювань печінки (AASLD) [8], НАЖХП діагностується при наявності 4 обов'язкових критеріїв: (1) стеатоз більше 5\% гепатоцитів, встановлений гістологічним дослідженням біоптату печінки, або жирові зміни печінки, які спостерігаються при ультразвуковій візуалізації; (2) відсутність вираженої алкогольної звички (споживання етанолу <210 г/тиждень для чоловіків і <140 г/тиждень для жінок); (3) відсутність інших фракторів, що викликають жирові зміни печінки; і (4) - відсутність інших причин хронічного захворювання печінки. За клінічними рекомендаціями Європейських асоціацій з вивчення хвороб печінки (EASL), діабету (EASD) і ожиріння (EASO) [12], НАЖХП діагностують при наявності стеатозу більш ніж $5 \%$ гепатоцитів за даними гістологічного дослідження або при наявності $>5,6 \%$ жирової фракції за даними протонної магнітнорезонансної спектроскопії або магнітно-резонансної томографії. Для виключення альтернативних причин стеатогепатиту необхідні додаткові лабораторно-діагностичні дослідження вірусного гепатиту В і C, аутоімунних маркерів, насичення трансферину, іноді - рівня а1-антитрипсину і церулоплазміну [9].

При диференційній діагностиці хронічного вірусного гепатиту і хронічного стеатогепатиту нами встановлено, що при ХВГ С має місце мікро-макровезікулярний стеатоз $>5 \%$ гепатоцитів різних зон печінкових часточок, а також наявність дрібних локусів стеатопеліозу в зонах максимального мікро-макровезікулярного стеатозу ге- патоцитів. ХВГ С, асоційований зі стеатозом печінки, в порівнянні з хронічним стеатогепатитом неалкогольного і алкогольного ґенезу в активній фазі, відрізняє більш виразний імуноклітинний компонент: значна інфільтрація лімфоцитами перисинусоїдальних просторів, дифузна або фоллікулоподібна інфільтрація портальних трактів CD20 +, CD8 +, CD45R0 + i CD5 + лімфоцитами, а також імуноклітинна деструкція печінки: наявність імуноклітинних портально-часточкових і перипортальних "східчастих некрозів", в яких переважають CD8 + Tлімфоцити, CD68 + макрофраги, CD20 + В-лімфоцити 3 домішком NK-клітин і a-SMA + фрібробластів, а також внутрішньочасточкових вогнищ імуноклітинного кілінга гепатоцитів.

Нами, враховуючи клініко-лабораторні дані про дисфункцію печінки на момент проведення трепанобіопсії, визначено, що ПМ проявами активності хронічного СГ у хворих на НАСГ і АСГ є зростання тяжкості стеатозу печінки до панлобулярного; збільшення числа гепатоцитів 3 тільцями Малорі-Денка, балонних гепатоцитів та гепатоцитів в стані стеатонекрозу і апоптозу; а також розширення вогнищ стеатонекроза в печінці та поширення запально-клітинної інорільтрації печінки. Рідкими проявами активності стеатогепатиту є значний стеатонекроз і аутофагія в гепатоцитах (частіше при НАСГ), зверхнакопичення заліза в гепатоцитах та поява стеатогранульом (частіше при АСГ). Повторні біопсії печінки у хворих на НАСГ показали, що стеатоз гепатоцитів $є$ лабільним і транзиторним процесом. За даними P. Sakhuja [19] при тяжкому АСГ стеатоз печінки знижується після періодів абстиненції, охоплюючи менше $5 \%$ гепатоцитів.

Важливим для ПМ оцінки активності стеатогепатиту в трепанобіоптаті печінки $є$ врахування сукупності всіх перерахованих мікроскопічних параметрів, кожен з яких окремо може значно варіювати у різних хворих. Ймовірно, через значну варіабельність мікроскопічних ознак хронічного стеатогепатиту до теперішнього часу міжнародним групам патоморфологів не вдалося розробити прийнятну кількісно-бальну схему діагностики та тяжкості НАСГ: як в схемі NAS по D.E. Kleiner et al. [15], так і в класифікаційній схемі C.A. Matteoni et al. [16] і в діагностичній схемі Z.M. Younossi et al. [25]. У 2011 році E.M. Brunt et al. [6] опублікували дані про те, що діагноз і прогноз НАСГ більш точно відображає схема Маттеоні, ніж НАС. Схема Маттеоні корисна для повсякденної клінічної практики, досліджень в одній установі і для вивчення канцерогенезу; в той час як NAS треба використовувати не для діагностики НАСГ, а для багатоцентрових клінічних досліджень за участю багатьох діагностів і для оцінки терапевтичного ефекту ліків [6].

Нами [1] визначено, що у померлих хворих на АСГ з різним ступенем тяжкості стеатозу печінки достовірно відрізняється ступінь депонування заліза в гепатоцитах і макрофрагах: клітини, що містять тривалентне $\mathrm{Fe} 3+$ за-

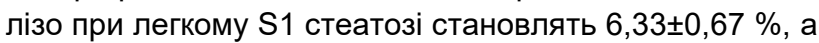

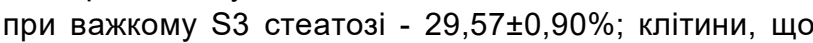


містять двовалентне Fe2+ залізо при легкому S1 стеатозі становлять $0,67 \pm 0,33 \%$, а при помірному S2 стеа-

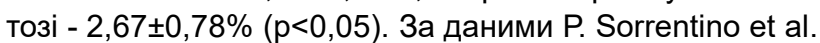
[20] надмірне накопичення заліза в гепатоцитах запускає прогресування простого стеатозу печінки в НАСГ і в цироз печінки. За результатами наших досліджень при значному накопиченні в цитоплазмі гепатоцитів тривалентного $\mathrm{Fe}^{3+}$ і двовалентного $\mathrm{Fe}^{2+}$ заліза гепатоцити піддаються фрерроптозу. Це свідчить про те, що значне депонування заліза в гепатоцитах і макрофагах $€$ ознакою активності АСГ.

Гістохімічні і ІГХ дослідження показали, що перисинусоїдально-перицелюлярний і портально-Z1-Зперисинусоидальний фіброз печінки, який прогресує через достовірне накопичення колагену I, III і IV типу від легкого F1 фіброзу до цирозу печінки, є достовірним ПМ показником тяжкості і тривалості НАСГ і АСГ. Паралельна ФЦММ площі фіброзу печінки різного ступеня тяжкості у хворих на НАСГ, що визначається при забарвленні за Масон-триколор, а також за експресією колагену I, III і IV типу, показала повну прийнятність методу Масон-триколор для оцінки тяжкості фріброзу печінки.

Нами [2] встановлено, що у хворих на НАСГ медіана площі перисинусоїдально-перицелюлярного фіброзу легкого $F_{1}$ ступеня становить 12,05 (11,01; 13,97)\% СПГЗП (що більш, ніж у 10 разів перевищує площу фррагментарного фіброзу печінки пацієнтів без стеатогепатиту) , помірного $F_{2}$ фріброзу печінки - 17,50 (16,00; $20,65) \%$ СПГЗП, тяжкого $\mathrm{F}_{3}$ фіброзу печінки становить $23,54(19,12 ; 26,47) \%$ СПГЗП, а вкрай тяжкого $\mathrm{F}_{4}$ фріброзу/цирозу печінки сягає 29,18 (26,93; 30,65)\% СПГЗП. Збільшення площі перисинусоїдально-перицелюлярного фріброзу печінки у міру зростання ступеня його тяжкості є статистично достовірним $(\mathrm{H}=88,70 ; \mathrm{p}<0,05)$.

Аналогічну спрямованість має достовірне зростання експресії колагену I, III i IV типу в динаміці прогресування фріброзу печінки. При еволюції фріброзу від легкого $\mathrm{F}_{1}$ ступеня до $\mathrm{F}_{4}$ фіброзу/цирозу печінки площа перицелюлярного колагену I і IV типу зростає більш ніж в 2 рази, площа депонування перицелюлярного колагену III типу при легкому $F_{1}$ фріброзі достовірно зростає в 10 разів і становить $11,29(9,59 ; 19,71) \%$ СПГЗП, при F2 фріброзі - підвищується до 17,07 $(15,22 ; 18,58) \%$ СПГЗП і надалі стабілізується на рівні $14,11(13,35 ; 14,54) \%$ СПГЗП, що в 14 разів вище, ніж у пацієнтів контрольної групи. Фіналом прогресування фіброзу печінки у хворих на НАСГ і АСГ є мікронодулярний цироз печінки перисинусоїдально-перицелюлярного і портально- $Z_{1-3}$ перисинусоидального типу, при якому фрормуються псевдочасточки, облямовані фріброзними септами з найвищим вмістом колагену I, III і IV типу за площею їх депонування в печінці.

При НАСГ і АСГ встановлені деякі ПМ особливості репаративних процесів в печінці, які мають завуальовану гепатоцитарну складову і яскраво виражену фіброзну складову. Загибель гепатоцитів при НАСГ та АСГ рано активує перицелюлярний фіброз, при якому тривалий час не стимулюється мітотична активність гепатоцитів, що складає 1-3\% (за рівнем ІГХ ядерної експресії Кі-67), а активуються компенсаторні зміни в гепатоцитах (двошестиядерні клітини, гігантоядерні гепатоцити). На стадії помірного $\mathrm{F}_{2}$ - тяжкого $\mathrm{F}_{3}$ фріброзу і цирозу печінки активується репаративний комплекс прогеніторних клітин печінки з дуктулярною реакцією, в активній фразі якої в проекції канальців Герінга розкривається ніша прогеніторних клітин печінки: з'являються скупчення і ланцюжки з невеликих "овальних" епітеліоподобних клітин, що переходять в дрібні розгалужені дуктули з таких же клітин. Нами визначено [3], що реактивні дуктули, клітинні ланцюжки і скупчення містять нечисленні клітини прогеніторного імунофенотипу (c-kit CD117 +, CD34 +, CD56 +, CD44 Std./HCAM+, a-FTP +, CK7 -, СК19-, Hepar-), клітини проміжного гепато-біліарного диференціювання (CK7 +, СК19 +, Hepar +, a-FTP +), біліарного $($ CK7 +, СК19 +) i гепатоцитарного диференціювання (Hepar + i a-FTP +). В клітинних скупченнях і ланцюжках в активній фразі дуктулярної реакції має місце проліферація дрібних "овальних" клітин (за експресією Кі-67). Незважаючи на те, що ще в 2004 році T. Roskams et al. [18] описали здатність прогеніторних клітин печінки після їх ампліфікації диференціюватися в гепатоцити і в біліарні клітини, в подальшому дослідники дуктулярної реакції основну увагу приділили її холангіо-дуктулярному компоненту при хронічних холангіопатіях $[7,13]$, в той час як її гепатоцелюлярний компонент залишився не вивченим.

Нами визначено, що на наступному етапі реактивні дуктули і клітинні ланцюжки або просуваються в дольки печінки, або залишаються в перипортальних зонах, або просуваються по міжлобулярних просторах. У часточках печінки клітини реактивних дуктул і клітинних ланцюжків гепатобіліарного диференціювання (CK7 +, СК19 +, Hepar +, a-FTP +), біліарного $(\mathrm{CK} 7+$, CK19 +) і гепатоцитарного диференціювання (Hepar + i a-FTP +) диференціюються в гепатоцити. Про це свідчить поява в дольках великих CK7-позитивних клітин, схожих з гепатоци-

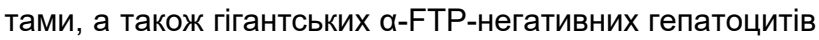
з інтенсивною цитоплазматичною експресією Hepar. Таким чином, прогеніторні клітини печінки через проміжні гепатобіліарні і гепатоцитоподібні клітини диференціюються в гепатоцити. Зараз встановлено, що в диференціації прогеніторних клітин печінки активну роль виконують Notch-сигнали і Wnt-білки: при біліарному диференціюванні МФБ підсилюють Notch-сигналізацію і диференціювання прогеніторних клітин у холангіоцити; при зниженні Notch-сигналів і активації секреції макрофагами Wnt3a прогеніторні клітини паралельно диференціюються в гепатоцити [10]. Виконаний нами ІГX аналіз ПКМ показав, що гепатоцитарному диференціюванню прогеніторних клітин сприяє наявність ламініну в нішах прогеніторних клітин і поява експресії ламініну в дольках печінки навколо реактивних дуктул і в прилеглих до них відростках перисинусоїдальних зірчастих 
клітин (в нормі ламінін в дольках відсутній). За даними L.K. Kanninen et al. [14] саме ламінін підтримує гепатоцитарну спеціалізацію культивованих плюрипотентних стовбурових клітин людини.

У результаті активації репаративної дуктулярної реакції при цирозі печінки в дольках з перисинусоїдально-перицелюлярним фіброзом з'являються нові псевдочасточки без наявності лінійно орієнтованих синусоїдальних просторів і центролобулярних вен - у вигляді скупчень неупорядковано розташованих, великих Hepar + i a-FTP- гепатоцитів. При важкому мікронодулярному цирозі печінки, коли площа псевдодольок стає рівною або меншою площі прилеглого до них фріброзу, має місце паралельне зростання числа Кi-67 + клітин в портально-долькових дуктулах, а також числа Ki-67 + гепатоцитів в печінкових псевдочасточках.

Реактивні дуктули, що залишилися на місці колишньої ніші прогеніторних клітин, збільшують кількість портально-перипортальних холангіол, а їх перидуктальні МФБ збільшують площу портально-перипортального фіброзу. Разом з цим, МФБ реактивних дуктул, що просунулися в міжлобулярні простори, формують мостоподібний портально-портальний фіброз. Аналіз гістотопографрії і структурно-імуногістохімічних особливостей реактивних дуктул і клітинних ланцюжків дозволяє патоморфологу з певною ймовірністю визначити спрямованість і фрінал репаративної дуктулярної реакції: або поповнення популяції гепатоцитів, або посилення перипортального і портально-портального мостоподібного фріброзу печінки. За літературними даними дуктулярна реакція при НАСГ корелює зі стадією прогресії фріброзу печінки [26]. Таким чином, при репарації стеатогепа-

\section{Список посилань}

1. Туманский, В. А., \& Фень, С. В. (2015). Особенности депонирования разновалентного железа (Fe2+ и $\mathrm{Fe} 3+)$ в печени при алкогольном и неалкогольном стеатогепатите. Патологія, 35 (3), 41-48. doi: 10.14739/23101237.2015.3.55589.

2. Туманский, В. А., \& Фень, С. В. (2017). Патоморфология фиброза печени в трепанобиоптатах больных стеатогепатитом: основные типы, источники развития, особенности прогрессирования. Патологія, 14, 3 (41), 244-256. DOI: 10.14739/2310-1237. 2017.3.118299.

3. Туманский, В. А., \& Фень, С. В. (2018). Дуктулярная реакция, или печеночный репаративный комплекс: иммуногистохимические особенности при циррозе печениу больных хроническим гепатитом. Патологія, 15, 1 (42), 18 28. DOI: 10.14739/2310-1237. 2018.1.129316.

4. Askgaard, G., Leon, D.A., Kjaer, M.S., Deleuran, T., Gerds, T. A., \& Tolstrup, J. S. (2017). Risk for alcoholic liver cirrhosis after an initial hospital contact with alcohol problems: A nationwide prospective cohort study. Hepatology, 65, 929937. doi: 10.1002/hep.28943.

5. Bedossa, P. (2014). Utility and appropriateness of the fatty liver inhibition of progression (FLIP) algorithm and steatosis, activity, and fibrosis (SAF) score in the evaluation of biopsies of nonalcoholic fatty liver disease. Hepatolog, 60, 565-575. doi: 10.1002/hep.27173.

6. Brunt, E. M., Kleiner, D. E., Wilson, L. A., Belt, P., \& титу важливу роль відіграє активація двох фріброзних шляхів: в ранньому періоді перицелюлярний фіброгенез обумовлений активацією пошкодженими гепатоцитами перисинусоїдальних МФБ; в пізньому періоді активується дуктулярна реакція, при якій перидуктальні МФБ підсилюють портальний і мостоподібний портально-портальний фріброз.

\section{Висновки та перспективи подальших розробок}

1. При застосуванні мінімуму гістохімічних (забарвлення за Ван Гізон, Масон-триколор, при необхідності заліза) і імуногістохімічних (Hepar, CK7, a-SMA, Laminin, Ki-67) методик, адекватний за фріксацією, довжиною і числом стовпчиків тканини трепанобіоптат печінки дає можливість патоморфологу встановити активність хронічного стеатогепатиту (або її відсутність), тип і ступінь тяжкості фіброзу печінки, а також наявність, ступінь виразності і спрямованість репаративних процесів в печінці; ґенез стеатогепатиту (алкогольний, неалкогольний, вірусний, токсичний) уточнюється тільки з урахуванням відповідних клініко-лабораторних даних пацієнта.

2. Структурно-імуногістохімічні і гістотопографічні особливості репаративної дуктулярної реакції в трепанобіоптаті печінки дають можливість визначити її спрямованість: або поповнення популяції гепатоцитів в дольках печінки, або прогресування перипортального і мостоподібного портально-портального фріброзу, або збільшення числа псевдочасточок при цирозі печінки.

Перспективним $€$ подальше визначення ролі стовбурових клітин кісткового мозку в репаративних процесах при хронічному стеатогепатиті.

Neuschwander-Tetri, B.A. (2011). Nonalcoholic fatty liver disease (NAFLD) activity score and the histopathologic diagnosis in NAFLD: distinct clinicopathologic meanings. Hepatology, 53, 810-820. doi: 10.1002/hep.24127.

7. Carpino, G., Renzi, A., Onori, P., \& Gaudio, E. (2013). Role of hepatic progenitor cells in nonalcoholic fatty liver disease development: cellular cross-talks and molecular networks. Int. J. Mol. Sci., 14 (10), 20112-20130. doi: 10.3390/ ijms141020112.

8. Chalasani, N., Younossi, Z., Lavine, J.E., Diehl, A.M., Brunt, E.M., Cusi, K., ... Sanyal, A. J. (2012). The diagnosis and management of non-alcoholic fatty liver disease: practice Guideline by the American Association for the Study of Liver Diseases, American College of Gastroenterology and the American Gastroenterological Association. Hepatology, 55, 2005-2023. doi.org/10.1002/hep.25762.

9. Crabb, D. W., Bataller, R., Chalasani, N. P., Kamath, P. S., Lucey, M., Mathurin, P., ... Szabo, G. (2016). Standard definitions and common data elements for clinical trials in patients with alcoholic hepatitis: recommendation From the NIAAA alcoholic hepatitis consortia. Gastroenterology, 150, 785-790. doi: 10.1053/ j.gastro.2016.02.042.

10. De Luca-Johnson, J., Wangensteen, K. J., Hanson, J., Krawitt, E., \& Wilcox, R. (2016). Natural history of patients presenting with autoimmune hepatitis and coincident nonalcoholic fatty liver disease. Dig. Dis. Sci., 61, 2710-2720. doi: 10.1007/ 
s10620-016-4213-3.

11. EASL (2018). Clinical Practice Guidelines: Management of alcohol-related liver disease. European Association for the Study of the Liver. J. Hepatol., 69, 154-181.

12. EASL-EASD-EASO (2016). Clinical Practice Guidelines for the management of non-alcoholic fatty liver disease. J. Hepatol., 64, 1388-1402.

13. Fabris, L., Spirli, C., Cadamuro, M., Fiorotto, R., \& Strazzabosco, M. (2017). Emerging concepts in biliary repair and firosis. Am. J. Physiol. Gastrointest. Liver Physiol., 313 (2), 102-116. doi: 10.1152/ajpgi.00452.2016.

14. Kanninen, L. K., Harjumaki, R., Peltoniemi, P., Bogacheva, M. S., Salmi, T., Porola, P., ... Lou, Y. R. (2016). Laminin-511 and laminin-521-based matrices for efficient hepatic specification of human pluripotent stem cells. Biomaterials, 103, 86-100. doi: 10.1016/j.biomaterials.2016.06.054.

15. Kleiner, D. E., Brunt, E. M., Van Natta, M., Behling, C., Contos, M. J., Cummings, O. W., ... Sanyal, A. J.(2005). Design and validation of a histological scoring system for nonalcoholic fatty liver disease. Hepatology, 41 (6), 1313-1321. DOI: 10.1002/hep.20701.

16. Matteoni, C. A., Younossi, Z. M., Gramlich, T., Boparai, N., Liu, Y. C., \& McCullough, A. J. (1999). Nonalcoholic fatty liver disease: a spectrum of clinical and pathological severity. Gastroenterology, 116, 1413-1419.

17. Rasband, W. S., \& Image J. US National Institutes of Health, Bethesda, Maryland, USA, https://imagej.nih.gov/ij/, 1997-2018.

18. Roskams, T. A., Theise, N. D., Balabaud, C., Bhagat, G., Bhathal, P. S., Bioulac-Sage, P., ... West, A. B. (2004). Nomenclature of the finer branches of the biliary tree: canals, ductules, and ductular reactions in human livers. Hepatology, 239, 17391745. DOI: $10.1002 /$ hep. 20130.

19. Sakhuja, P. (2014). Pathology of alcoholic liver disease, can it be differentiated from nonalcoholic steatohepatitis. World J. Gastroenterol, 20 (44), 16474-16479. URL : doi.org/10.3748/ wjg.v20.i44.16474].

20. Sorrentino, P., D'Angelo, S., Ferbo, U., Micheli, P., Bracigliano, A., \& Vecchione, R. (2010). Liver iron excess in patients with hepatocellular carcinoma developed on non-alcoholic steatohepatitis. J. Hepatol., 50 (2), 351-357. doi: 10.1016/ j.jhep.2008.09.011

21. Torbenson, M. (2009). Classification of iron grading. In: Book Liver Pathology, 537

22. Vernon, G., Baranova, A., \& Younossi, Z. M. (2011). Systematic review: the epidemiology and natural history of non-alcoholic fatty liver disease and non-alcoholic steatohepatitis in adults. Aliment. Pharmacol. The., 34, 274-285. doi: 10.1111/j.13652036.2011.04724.x.

23. Vuppalanchi, R., Unalp, A., Van Natta, M. L., Cummings, O. W., Sandrasegaran, K. E., Hameed, T., ... Chalasani, N.(2009). Effects of liver biopsy sample length and number of readings on sampling variability in nonalcoholic Fatty liver disease. Clin. Gastroenterol. Hepatol., 7, 481-486. doi: 10.1016/ j.cgh.2008.12.015.

24. World Health Organization. WHO mortality database: raw data files. Geneva. Geneva : WHO, 2018. www.who.int/healthinfo/ .../mortality rawdata/en/index1.]

25. Younossi, Z. M., Stepanova, M., Rafiq, N., Makhlouf, H., Younoszai, Z., Agrawal, R., \& Goodman, Z. (2011). Pathologic criteria for nonalcoholic steatohepatitis: interprotocol agreement and ability to predict liver-related mortality. Hepatology, 53, 1874-1882. doi: 10.1002/hep.24268.

26. Zhao, L., Westerhoff, M., Pai, R. K., Choi, W. T., Gao, Z.H., \& Hart, J. (2017). Centrilobular ductularre action correlates with fibrosis stage and fibrosis progression in non-alcoholic steatohepatitis. Modern Pathology advance online publication, 31 (1), 150-159. doi: 10.1038/modpathol.2017.115.

\section{References}

1. Tumansky, V. A., \& Fen, S. V. (2015). Peculiarities of the depositing of nonvalent iron $(\mathrm{Fe} 2+$ and $\mathrm{Fe} 3+)$ in the liver during alcoholic and nonalcoholic steatohepatitis [Features of depositing razovalentnogo gland $(\mathrm{Fe} 2+$ and $\mathrm{Fe} 3+)$ in the liver with alcohol and non-alcoholic steatohepatite]. Patolohiia Pathology, 35 (3), 41-48. doi: 10.14739/23101237.2015.3.55589.

2. Tumanskij, V. A., \& Fen, S. V. (2017). Patomorfologiya fibroza pecheni v trepanobioptatah bolnyh steatogepatitom: osnovnye tipy, istochniki razvitiya, osobennosti progressirovaniya [Pathomorphology of liver fibrosis in trepanobiopaths of patients with steatohepatitis: main types, sources of development, features of progression]. Patolohiia - Pathology, 14, 3 (41), 244-256. DOI: 10.14739/2310-1237. 2017.3.118299.

3. Tumanskij, V. A., \& Fen, S. V. (2018). Duktulyarnaya reakciya, ili pechenochnyj reparativnyj kompleks: immunogistohimicheskie osobennosti pri cirroze pecheniu bolnyh hronicheskim gepatitom [Ductular reaction, or hepatic reparative complex: immunohistochemical features in liver cirrhosis in patients with chronic hepatitis]. Patolohiia Pathology, 15, 1 (42), 18-28. DOI: 10.14739/2310-1237. 2018.1.129316.

4. Askgaard, G., Leon, D.A., Kjaer, M.S., Deleuran, T., Gerds, T. A., \& Tolstrup, J. S. (2017). Risk for alcoholic liver cirrhosis after an initial hospital contact with alcohol problems: A nationwide prospective cohort study. Hepatology, 65, 929937. doi: 10.1002/hep.28943.

5. Bedossa, P. (2014). Utility and appropriateness of the fatty liver inhibition of progression (FLIP) algorithm and steatosis, activity, and fibrosis (SAF) score in the evaluation of biopsies of nonalcoholic fatty liver disease. Hepatolog, 60, 565-575. doi: 10.1002/hep.27173.

6. Brunt, E. M., Kleiner, D. E., Wilson, L. A., Belt, P., \& Neuschwander-Tetri, B.A. (2011). Nonalcoholic fatty liver disease (NAFLD) activity score and the histopathologic diagnosis in NAFLD: distinct clinicopathologic meanings. Hepatology, 53, 810-820. doi: 10.1002/hep.24127.

7. Carpino, G., Renzi, A., Onori, P., \& Gaudio, E. (2013). Role of hepatic progenitor cells in nonalcoholic fatty liver disease development: cellular cross-talks and molecular networks. Int. J. Mol. Sci., 14 (10), 20112-20130. doi: 10.3390/ ijms141020112.

8. Chalasani, N., Younossi, Z., Lavine, J.E., Diehl, A.M., Brunt, E.M., Cusi, K., ... Sanyal, A. J. (2012). The diagnosis and management of non-alcoholic fatty liver disease: practice Guideline by the American Association for the Study of Liver Diseases, American College of Gastroenterology and the American Gastroenterological Association. Hepatology, 55, 2005-2023. doi.org/10.1002/hep.25762.

9. Crabb, D. W., Bataller, R., Chalasani, N. P., Kamath, P. S., Lucey, M., Mathurin, P., ... Szabo, G. (2016). Standard definitions and common data elements for clinical trials in patients with alcoholic hepatitis: recommendation From the NIAAA alcoholic hepatitis consortia. Gastroenterology, 150, 785-790. doi: 10.1053/ j.gastro.2016.02.042.

10. De Luca-Johnson, J., Wangensteen, K. J., Hanson, J., Krawitt, E., \& Wilcox, R. (2016). Natural history of patients presenting with autoimmune hepatitis and coincident nonalcoholic fatty liver disease. Dig. Dis. Sci., 61, 2710-2720. doi: 10.1007/ s10620-016-4213-3.

11. EASL (2018). Clinical Practice Guidelines: Management of alcohol-related liver disease. European Association for the Study of the Liver. J. Hepatol., 69, 154-181.

12. EASL-EASD-EASO (2016). Clinical Practice Guidelines for the management of non-alcoholic fatty liver disease. J. Hepatol., 64, 1388-1402. 
13. Fabris, L., Spirli, C., Cadamuro, M., Fiorotto, R., \& Strazzabosco, M. (2017). Emerging concepts in biliary repair and firosis. Am. J. Physiol. Gastrointest. Liver Physiol., 313 (2), 102-116. doi: 10.1152/ajpgi.00452.2016.

14. Kanninen, L. K., Harjumaki, R., Peltoniemi, P., Bogacheva, M. S., Salmi, T., Porola, P., ... Lou, Y. R. (2016). Laminin-511 and laminin-521-based matrices for efficient hepatic specification of human pluripotent stem cells. Biomaterials, 103, 86-100. doi: 10.1016/j.biomaterials.2016.06.054.

15. Kleiner, D. E., Brunt, E. M., Van Natta, M., Behling, C., Contos, M. J., Cummings, O. W., ... Sanyal, A. J.(2005). Design and validation of a histological scoring system for nonalcoholic fatty liver disease. Hepatology, 41 (6), 1313-1321. DOI: 10.1002/hep.20701.

16. Matteoni, C. A., Younossi, Z. M., Gramlich, T., Boparai, N., Liu, Y. C., \& McCullough, A. J. (1999). Nonalcoholic fatty liver disease: a spectrum of clinical and pathological severity. Gastroenterology, 116, 1413-1419.

17. Rasband, W. S., \& Image J. US National Institutes of Health, Bethesda, Maryland, USA, https://imagej.nih.gov/ij/, 1997-2018.

18. Roskams, T. A., Theise, N. D., Balabaud, C., Bhagat, G., Bhathal, P. S., Bioulac-Sage, P., ... West, A. B. (2004). Nomenclature of the finer branches of the biliary tree: canals, ductules, and ductular reactions in human livers. Hepatology, 239, 17391745. DOI: $10.1002 /$ hep. 20130

19. Sakhuja, P. (2014). Pathology of alcoholic liver disease, can it be differentiated from nonalcoholic steatohepatitis. World J. Gastroenterol, 20 (44), 16474-16479. URL : doi.org/10.3748/ wjg.v20.i44.16474]

20. Sorrentino, P., D'Angelo, S., Ferbo, U., Micheli, P., Bracigliano,
A., \& Vecchione, R. (2010). Liver iron excess in patients with hepatocellular carcinoma developed on non-alcoholic steatohepatitis. J. Hepatol., 50 (2), 351-357. doi: 10.1016/ j.jhep.2008.09.011.

21. Torbenson, M. (2009). Classification of iron grading. In: Book Liver Pathology, 537.

22. Vernon, G., Baranova, A., \& Younossi, Z. M. (2011). Systematic review: the epidemiology and natural history of non-alcoholic fatty liver disease and non-alcoholic steatohepatitis in adults. Aliment. Pharmacol. The., 34, 274-285. doi: 10.1111/j.13652036.2011.04724.x.

23. Vuppalanchi, R., Unalp, A., Van Natta, M. L., Cummings, O. W., Sandrasegaran, K. E., Hameed, T., ... Chalasani, N.(2009). Effects of liver biopsy sample length and number of readings on sampling variability in nonalcoholic Fatty liver disease. Clin. Gastroenterol. Hepatol., 7, 481-486. doi: 10.1016/ j.cgh.2008.12.015.

24. World Health Organization. WHO mortality database: raw data files. Geneva. Geneva : WHO, 2018. www.who.int/healthinfo/ .../mortality_rawdata/en/index1.]

25. Younossi, Z. M., Stepanova, M., Rafiq, N., Makhlouf, H., Younoszai, Z., Agrawal, R., \& Goodman, Z. (2011). Pathologic criteria for nonalcoholic steatohepatitis: interprotocol agreement and ability to predict liver-related mortality. Hepatology, 53, 1874-1882. doi: 10.1002/hep.24268.

26.Zhao, L., Westerhoff, M., Pai, R. K., Choi, W. T., Gao, Z.H., \& Hart, J. (2017). Centrilobular ductularre action correlates with fibrosis stage and fibrosis progression in non-alcoholic steatohepatitis. Modern Pathology advance online publication, 31 (1), 150-159. doi: 10.1038/modpathol.2017.115.

\section{ХРОНИЧЕСКИЕ СТЕАТОГЕПАТИТЫ В ТРЕПАНОБИОПТАТАХ ПЕЧЕНИ: ПАТОМОРФОЛОГИЯ АКТИВНОСТИ И РЕПАРАТИВНЫХ ПРОЦЕССОВ}

\section{Туманский В.А., Фень С.В., Туманская Л.М.}

Аннотация. Цель работы - охарактеризовать возможности патоморфологического определения в трепанобиоптатах печени активности хронического стеатогепатита различного генеза и направленности репаративных процессов. Гистологическими, гистохимическими и иммуногистохимическими методами исследована печень 160 больных алкогольным стеатогепатитом (АСГ), 123 больных неалкогольным стеатогепатитом (НАСГ), 30 больных хроническим вирусным гепатитом C, а также 30 гепатобиоптатов пациентов, не болевиих стеатогепатитом. Установлено, что патоморфологическими параметрами активности АСГ и НАСГ является рост тяжести и распространенности стеатоза гепатоцитов печени увеличение числа гепатоцитов с тельцами Малоори-Денка и баллонных гепатоцитов; интенсификация стеатонекроза, баллонного лизиса, апоптоза и ферроптоза гепатоцитов; рост числа и расширение очагов стеатонекроза в печени; распространение очаговой и дифффузной лейкоцитарно-лимфоцитарной инфильтрации долек печени. Генез стеатогепатита (алкогольный, неалкогольный, вирусный) уточняется только с учетом соответствующих клинико-лабораторных данных пациента. Особенностями репаративных процессов в печени являются: диффреренцировка прогениторных клеток печени через промежуточные гепатобилиарные и гепатоцитоподобные клетки в гепатоциты при наличии ламинина в печеночных дольках; раннее развитие перицеллюлярного фиброза и отсроченная активация дуктулярной реакиии с усилением портального и мостовидного портально-портального фиброза; финалом фриброза является микронодулярный цирроз печени перисинусоидально-перицеллюлярного или портально-Z1-Зперисинусоидального типа. Таким образом, в адекватном трепанобиоптате печени имеется возможность определить активность НАСГ и АСГ (или ее отсутствие), тип и степень тяжести фриброза печени, а также степень выраженности и направленность репаративных процессов в печени.

Ключевые слова: стеатогепатит, патоморфология, репаративные процессы, биопсия печени.

\section{CHRONIC STEATOHEPATITIS IN LIVER FINE-NEEDLE ASPIRATION BIOPSY: THE PATHOMORPHOLOGY OF ACTIVITY AND REPARATIVE PROCESSES \\ Tumanskiy V.A., Fen' S.V., Tumanskaya L.M.}

Annotation. Purpose of the work - to characterize the possibilities of pathomorphological determination in liver fine-needle aspiration biopsy activities of chronic steatohepatitis of various origins and directionality of reparative processes. The liver examined of 160 patients with alcoholic steatohepatitis (ASH), 123 patients with nonalcoholic steatohepatitis (NASH), 30 patients with chronic viral hepatitis C, and 30 hepatobiopsy patients who did not suffer from steatohepatitis, using histological, histochemical and immunohistochemical methods. It was established that the pathomorphological parameters of the activity of ASH and NASH is an increase in the severity and prevalence of hepatocyte steatosis of the liver; an increase in the number of hepatocytes with Mallory-Denk bodies and balloon hepatocytes; intensification of steatonecrosis, balloon lysis, apoptosis and hepatocyte ferroptosis; an increase in the number and expansion of foci of steatonecrosis in the liver; distribution of focal and diffuse leukocyte-lymphocytic infiltration of the 
liver lobules. The genesis of steatohepatitis (alcoholic, non-alcoholic, viral) is specified only with the relevant clinical and laboratory data of the patient. The peculiarities of the reparative processes in the liver are: the differentiation of progenitor liver cells through intermediate hepatobiliary and hepatocyte-like cells into hepatocytes in the presence of laminin in the hepatic lobules; early development of pericellular fibrosis and delayed activation of the ductular reaction with increased portal and bridge portal-portal fibrosis; the final fibrosis is micronodular cirrhosis of the perisinusoidal-pericellular or portal-Z1-3perisinusoidal type. Thus, in an adequate liver fineneedle aspiration biopsy, it is possible to determine the activity of NASH and ASH (or its absence), the type and severity of liver fibrosis, as well as the severity and direction of reparative processes in the liver.

Key words: steatohepatitis, pathomorphology, reparative processes, liver biopsy. 